\title{
Effect of simulated flooding during rice seed development and maturation on subsequent seed quality
}

Article

Accepted Version

Tejakhod, S. and Ellis, R. H. (2018) Effect of simulated flooding during rice seed development and maturation on subsequent seed quality. Seed Science Research, 28 (1). pp. 72-81. ISSN 0960-2585 doi:

https://doi.org/10.1017/S0960258517000368 Available at https://centaur.reading.ac.uk/74520/

It is advisable to refer to the publisher's version if you intend to cite from the work. See Guidance on citing.

To link to this article DOI: http://dx.doi.org/10.1017/S0960258517000368

Publisher: Cambridge University Press

All outputs in CentAUR are protected by Intellectual Property Rights law, including copyright law. Copyright and IPR is retained by the creators or other copyright holders. Terms and conditions for use of this material are defined in the End User Agreement.

www.reading.ac.uk/centaur 
Central Archive at the University of Reading

Reading's research outputs online 
Effect of simulated flooding during rice seed development and maturation on subsequent seed quality

Running head: Submergence of rice plants and seed quality

\section{Sujittra Tejakhod ${ }^{\dagger}$ and Richard H. Ellis ${ }^{*}$}

School of Agriculture, Policy and Development, University of Reading, Earley Gate, PO Box 237, Reading RG6 6AR, UK

*Correspondence

Email: r.h.ellis@ reading.ac.uk

†Present address: Division of Rice Seed, Rice Department, Ministry of Agriculture and Cooperatives, 50 Phaholyothin Road, Ladyao, Chatuchak, Bangkok, 10900 Thailand

Keywords: development, flooding, germination, longevity, Oryza sativa L, pre-harvest sprouting, rice

Financial support: RHE employed by and facilities of University of Reading; ST received a Royal Thai Government Scholarship. 


\section{Running head: Submergence of rice plants and seed quality}

\section{Abstract}

The resilience of seed quality in rice (Oryza sativa L.) to flooding was investigated. Potgrown plants of the japonica cv. Gleva, the indica cv. IR64, and the introgressed line IR64Sub1 were submerged in water, to simulate flooding, for 3-5 days at different stages of seed development and maturation. Mean seed weight, pre-harvest sprouting, ability to germinate, and subsequent longevity in air-dry storage were assessed. Whereas seed quality in both IR64 and IR64-Sub1 was resilient to submergence, in Gleva the longer the duration of submergence and the later in development when plants were submerged the greater the preharvest sprouting. Thousand seed dry weight was reduced more by submergence in Gleva than IR64 or IR64-Sub1. At harvest maturity, few pre-harvest sprouted seeds were able to germinate upon rehydration after desiccation to $11-12 \%$ moisture content. Seed longevity of the non-sprouted seed fraction in air-dry hermetic storage $\left(40{ }^{\circ} \mathrm{C}, 15 \%\right.$ moisture content) was not affected greatly by submergence, but longevity of the japonica rice was less than that of the indica rices due to the former's steeper seed survival curves. Longevity of the two indica rices was predicted well by the seed viability equation and previously-published estimates of viability constants for rice. The greater dormancy of IR64 and IR64-Sub1, compared to Gleva, enhanced resilience to pre-harvest sprouting and reduced thousand seed dry weight from plant submergence. There was little or no effect of plant submergence on subsequent air-dry storage longevity of non-sprouted seeds in any genotype.

Keywords: development, flooding, germination, longevity, Oryza sativa L, pre-harvest sprouting, rice 


\section{Introduction}

Heavy rainfall events are very likely and tropical cyclones more likely than not to continue to increase throughout the $21^{\text {st }}$ century with low-lying estuary deltas inundated more frequently (IPCC, 2013). The resilience of seed quality in rice (Oryza sativa L.) to flooding is therefore of growing concern. Flooding of rice crops in the reproductive phase may result in visible damage to seed from pre-harvest sprouting, but might it also affect the post-harvest air-dry survival of the remaining intact (i.e. non-sprouted) seeds?

Flooding reduces rice yield by 10-100\% depending upon variety, growth stage, plant nutrition, crop practices, duration of submergence, and flood water conditions (Yoshida, 1981; Reddy et al., 1985; Ram et al., 1999; Sharma and Ghosh, 1999; Kotera et al., 2005; Kotera and Nawata, 2007; Das et al., 2009; Dar et al., 2013). Submergence early in the vegetative stage reduces crop establishment and numbers of tillers and panicles, panicle size, and indeed plant survival after flood waters recede (Devender-Reddy and Mittra, 1985; Reddy et al., 1985; Sharma and Ghosh, 1999; Das et al., 2009; Singh et al., 2009; Singh et al., 2011). Flooding during the reproductive stage also damages yield, with pollen cell development, panicle formation or emergence, and progress to flowering impaired (Devender-Reddy and Mittra, 1985; Reddy et al., 1985; Kotera et al., 2005). Submergence shortly after panicle emergence may reduce seed set (Devender-Reddy and Mittra, 1985; Kotera and Nawata, 2007), whilst flooding during grain development disrupts yield accumulation (Kotera et al., 2005). Finally, towards the end of seed development and maturation, pre-harvest sprouting due to flooding or heavy rainfall is a major factor worldwide affecting both yield and quality in cereal crops generally (Gelin et al., 2006), particularly in rice. Pre-harvest sprouting of mature rice seeds coincides with wet and warm field conditions and leads to discoloured, cracked, lighter grains with poor cooking quality (Derera, 1989; Mahbub et al., 2005). 
Seed quality (ability to germinate, desiccation tolerance, and air-dry seed storage longevity) in rice improves considerably during seed filling and maturation (Ellis et al., 1993; Ellis and Hong, 1994; Ellis, 2011). The development of seed quality in rice can be limited in seed production environments subject to extreme temperature (Ellis et al., 1993; Ellis and Hong, 1994; Rao and Jackson, 1996; Martínez-Eixarch and Ellis, 2015). The effect of submergence in water during seed development and maturation on subsequent rice seed quality has been studied less than that of temperature. In some circumstances, certain aspects of seed quality may be improved by the temporary hydration of mature seeds ex planta, often known as priming (Heydecker et al., 1973; Heydecker and Gibbins, 1978). Recent research in wheat (Triticum aestivum L.) showed that, in the absence of pre-harvest sprouting, the reduction in subsequent air-dry seed storage longevity caused by rainfall could be reversed if it was followed by desiccation in planta (Ellis and Yadav, 2016; Yadav and Ellis, 2016).

Seed dormancy declines as seeds mature with pre-harvest sprouting in many cereals under moist field conditions if dormancy is lost before seed is harvested (Bewley and Black, 1994). Considerable differences in rice seed dormancy at maturity have been shown amongst different genotypes produced in the same field environment (Roberts, 1963). Japonica rice is more sensitive to seed production environment than indica (Chang, 1991; Ellis et al., 1993).

The Submergencel (Sub1) gene has been introgressed into selected indica rice genotypes to improve submergence tolerance (Septiningsih et al., 2009; Wassmann et al., 2009). The introgression line IR64-Sub1 has the Sub1-A-1 allele conferring tolerance of complete submergence for about 2 weeks whereas cv. IR64 carries the intolerant Sub1-A-2 allele (Singh et al., 2010). Septiningsih et al. (2009) reported that IR64-Sub1 endured submergence in the vegetative phase for up to 17 days and has inherited the grain quality of its recurrent parent cv. IR64. Such studies have been limited to submergence during vegetative growth (Septiningsih et al., 2009; Mackill et al., 2010; Singh et al., 2011); the 
resilience of seed quality in IR64-Sub1, relative to IR64, to plant submergence after anthesis has not been reported.

We tested the null hypotheses that flooding rice plants during seed development and maturation does not promote pre-harvest sprouting nor reduce seed dry weight, ability to germinate at harvest maturity, or subsequent longevity in air-dry storage. The latter was our principle objective, with the former variables determined to indicate the relative severity of treatments and vulnerability of plants. Flooding was simulated by submerging rice plants in water for different durations at different stages of seed development and maturation.

Contrasting genotypes of indica and japonica rice were selected for study. Indica rices are the more likely to be flooded in cultivation. On the other hand, seed quality in japonica rices tends to be less resilient to environment whilst some (including cv. Gleva used here) are grown in coastal areas vulnerable to flooding from future sea level rise. Hence both types were selected in order to test the hypotheses rigorously with contrasting genotypes, particularly whether or not flooding affected the post-harvest longevity of non-sprouted seeds.

\section{Materials and Methods}

Two experiments were conducted in successive years. The first, sown on 25 May 2012, comprised plants of the japonica rice cv. Gleva submerged for two durations (3, 5 days) at four different stages of seed development and maturation after anthesis $(9,30,35,40$ DAA) and a control (not submerged). The second, sown on 9 May 2013, comprised plants of three genotypes (Gleva plus the indica rices IR64 and IR64-Sub1) submerged for 4 days, and so within the 2-week period that the Subl locus confers submergence tolerance (Singh et al., 2010), at four different developmental stages (10, 30, 40 DAA) and controls. Durations from 
sowing to flowering are affected by photoperiod and temperature with rice genotypes varying in sensitivity (Summerfield et al., 1992). The quantitative phenological sensitivity of these three genotypes to photothermal environment was not known. Thus flowering could not be synchronized by adjusting sowing dates and so treatments were provided in relation to anthesis, not sowing date.

The plants were grown in pots in blocks (three in 2012, two in 2013) in a temperature and photoperiod controlled heated and vented glasshouse $(6.4 \times 8.6 \mathrm{~m})$ with four adjoining dark compartments (each $3.5 \times 2.1 \times 2.1 \mathrm{~m}$ ) at the Plant Environment Laboratory, Shinfield, $\mathrm{UK}\left(51^{\circ} 27^{\prime} \mathrm{N}\right.$ latitude, $00^{\circ} 56^{\prime} \mathrm{W}$ longitude). The growing media comprised steam-sterilized coarse sand, crushed gravel, peat compost, and vermiculite in the ratio 2:4:1:4. Slow-release fertilizer (Osmocote Pro 3-4M, Everris International BV, The Netherlands) containing $\mathrm{N}: \mathrm{P}_{2} \mathrm{O}_{5}: \mathrm{K}_{2} \mathrm{O}: \mathrm{MgO}(17: 11: 10: 2)$ was added at $3 \mathrm{~kg} \mathrm{~m}^{-3}$. The $18 \mathrm{~cm}$ diameter (3 litre) plastic pots (with drain holes) filled with the media were pre-soaked with tap water and left to drain overnight. Seven seeds were sown per pot. These pots were placed on trolleys (four, each 2.8 $\mathrm{x} 1.1 \mathrm{~m}$ with 75 pots) in the dark compartments at a constant temperature of $25^{\circ} \mathrm{C}$, initially. Temperatures were maintained at $28 / 20{ }^{\circ} \mathrm{C}$ day/night $(11 \mathrm{~h} / 13 \mathrm{~h})$ with synchronous thermoperiod and photoperiod $\left(11 \mathrm{~h} \mathrm{~d}^{-1}\right)$ from seedling emergence onwards (7 or 10 days after sowing (DAS) in 2012 and 2013, respectively): the plants on trolleys were moved from the dark compartments into the adjoining glasshouse at 0800 and back at 1900 each day. Seedlings were thinned to four per pot at the four-leaf stage (16-30 DAS, depending on cultivar). Pots were irrigated by hand with tap water until 14 DAS. Automatic drip feed irrigation (six times each day) was provided thereafter. The top of pots was $2 \mathrm{~cm}$ above the growing media and irrigation filled this gap on each occasion. The nutrient solution, derived from Yoshida et al. (1976), contained $100 \mathrm{mg} \mathrm{L}^{-1}$ inorganic nitrogen and was acidified to $\mathrm{pH}$ $5.0 \pm 0.2$. Savona (Koppert B.V., The Netherlands), an insecticidal soap containing $50 \%$ fatty 
acid from potassium salt, was used occasionally to control spider mites and aphids when detected.

Submergence, to simulate flooding, was carried out within a wooden tank $(2.4 \mathrm{x} 1.2 \mathrm{x}$ $1.1 \mathrm{~m}$ ) lined with black polythene in the same glasshouse, with air temperature maintained at $28{ }^{\circ} \mathrm{C}$ and natural light (i.e. ambient photoperiod for the duration of submergence). The tank was filled with new tap water before each submergence treatment to avoid contamination. Water was circulated by a $180 \mathrm{~W}$ pump (RG25, Stuart-Turner, UK) and aerated with four 50mm diameter, $14 \mathrm{~W}$ air-stones (Aqua One 12000, Precision Manufactured, Australia) at each corner throughout to avoid anoxia. Water temperature was associated with glasshouse air temperature, but not controlled directly, and during submergence plants differed slightly in temperature from those not submerged. All plants within a pot were staked to prevent lodging. Steam-sterilized gravel was added on top of the growing media to avoid the latter being dislodged during submergence. Submerged panicles were covered by water up to 80-95 $\mathrm{cm}$ deep controlled to $2 \mathrm{~cm}$ above the highest panicle. After submergence, plants were returned to their previous position on the trolley in the glasshouse and irrigation resumed.

Irrigation ended two days before seed harvest. Seeds were collected at harvest maturity (panicles yellow, grains firm). This was 47 DAA in 2012 and 46 DAA in 2013. Harvest date varied amongst genotypes in 2013 because of differences in flowering date. Empty seed were discarded and filled seed threshed from panicles by hand. Blocking was maintained throughout plant growth, submergence, harvest, and subsequent laboratory investigations.

Seed samples were air dried in the laboratory at $22 \pm 2{ }^{\circ} \mathrm{C}$ and changes in seed equilibrium relative humidity monitored (Humidat IC1, Novasina, Switzerland, in 2012; Aqualab, 3TE, Decagon Devices, Inc. Pullman, USA, in 2013). This regime was selected to 
provide a comparatively benign drying environment for seed quality (FAO/IPGRI, 1994). In hindsight, it avoided possible improvements that may occur in selected high-temperature regimes (Whitehouse et al., 2015, 2017). The seeds dried to 11-12\% moisture content over 14 days in 2012. In 2013 the seeds were wetter at harvest than in 2012 and more variable (because there were three cultivars). Most of these samples dried to 12-14\% moisture content over 14 days, but this period was extended to 20 days where necessary to dry to this value. Sprouted seeds (enlargement of micropyle, or emergence of radicle and/or shoot) were identified, separated, counted, and maintained as discrete sprouted seed samples. Subsamples were then drawn for the immediate tests. The remaining seed were sealed in laminated aluminium foil bags (Retort laminate, Moore and Buckle Ltd., St Helens, UK) and stored at 2-4 ${ }^{\circ} \mathrm{C}$ until experimental seed storage began.

The moisture content of mature seed was determined on two replicates of 2.5-3.0 $\mathrm{g}$ by the high-constant-temperature-oven method (ISTA, 2013) with ground seed (Laboratory Mill 3303, Perten Instruments Ab, Stockholm, Sweden) and calculated on the fresh weight basis. The two-stage procedure with pre-drying (ISTA, 2013) was used for less mature seeds harvested during seed development: one panicle from each block was selected with loss in moisture on pre-drying overnight at $30 \pm 2{ }^{\circ} \mathrm{C}$ determined as the first stage, the pre-dried samples ground, and the second-stage loss determined by the high-constant-temperature-oven method.

Thousand seed weight was determined by counting 800 seeds at random (ISTA, 2013) from samples of known moisture content and weighing using a balance to $0.1 \mathrm{mg}$ (Mettler Toledo, AE160, Greifensee, Switzerland).

The ability of (non-sprouted) seeds to germinate after harvest was estimated with two replicates of 50-70 seeds each between rolled paper towels [Kimberley Clark Professional 6803 HOSTESS, Natural, 24 x 35 cm, Greenham Sales, UK] moistened with deionized water, 
in an alternating temperature regime of $34 / 11^{\circ} \mathrm{C}(16 \mathrm{~h} / 8 \mathrm{~h})$ for 21 days, as recommended to break dormancy in rice (Ellis et al., 1983). The criterion of germination was normal seedling development (ISTA, 2013). In 2012, samples of dried, sprouted seeds (11-12\% moisture content) were also tested to assess their capability to germinate upon dehydration and reimbibition, with four replicates and a total of 200-280 seeds per sample.

Samples were stored in order to determine the effects of submergence on the longevity of non-sprouted seeds. The moisture content of samples was first determined and then adjusted to about $15 \%$ by humidification above water or by drying over silica gel at 20 ${ }^{\circ} \mathrm{C}$ (depending upon whether increase or reduction in moisture content was required). Seeds were left within sealed containers at $2-3{ }^{\circ} \mathrm{C}$ for $2-3$ weeks for moisture to equilibrate. Seed equilibrium relative humidity was then determined at $20{ }^{\circ} \mathrm{C}$ to estimate moisture content, and moisture content further adjusted towards $15 \%$. The moisture content of each seed sample was then determined by the high-constant-temperature-oven method.

After moisture equilibration, 10-15 sub-samples of seed (150-200 seeds each) from each seed sample were sealed within laminated aluminium foil bags (Moore and Buckle Ltd. St Helens, UK), stored hermetically in a heated incubator at $40 \pm 0.5{ }^{\circ} \mathrm{C}$ with $15.1 \pm 0.2 \%$ (2012) or $14.7 \pm 0.2 \%$ (2013) moisture content, sub-samples withdrawn at different periods of storage, and tested for ability to germinate (three replicates of 50-70 seeds). Seed survival curves (criterion, ability to produce normal seedlings) were fitted to the observations by probit analysis in accordance with the equation

$$
v=K_{i}-p / \sigma
$$

where $v$ is probit percentage viability after period $p$ (days) in storage in a constant environment, $K_{i}$ is the seed lot constant, and $\sigma$ (days) is the standard deviation of the frequency distribution of seed deaths in time (Ellis and Roberts, 1980). The product of $K_{i}$ and 
$\sigma$ is the period of storage (days) for viability to decline to $50 \%\left(p_{50}\right)$. This derived parameter was also selected to compare seed survival curves.

The progress of seed development and maturation was also compared amongst the genotypes Gleva, IR64 and IR64-Sub1 in 2013. Destructive serial harvests (one panicle taken at random from each of six non-submerged pots, threshed separately) were taken every 3-5 days from 8 DAA until harvest maturity at 47 DAA. Seeds were threshed from these panicle samples and mean seed weight and moisture content determined. In addition, for Gleva and IR64 only, the development of the ability of freshly-harvested seeds to germinate normally was determined. These germination tests comprised smaller samples of 24-70 full seeds (i.e. unfilled seeds were not tested). Seed covering structures were removed from seeds that remained firm after 21 days in test and the test extended to 28 days to promote loss in dormancy.

Analysis of variance, restricted maximum likelihood analysis, regression analysis, and probit analysis were applied to investigate the results using Genstat $\left(13^{\text {th }}\right.$ edition, VSN International Ltd., Hemel Hempstead, UK). Multiple comparisons of means for pre-harvest sprouting were performed using Tukey's test.

\section{Results}

Submergence resulted in considerable pre-harvest sprouting of seeds of Gleva produced in 2012 (Fig. 1). Pre-harvest sprouting was affected by duration $(P<0.001)$, plant developmental stage at submergence $(P<0.001)$, and their interaction $(P<0.05)$. It was greatest following 5 days' submergence 40 DAA and lower the earlier and briefer the submergence treatment, with no pre-harvest sprouting following submergence at 9 DAA. 
The moisture content of non-sprouted seeds at 47 DAA (harvest maturity) varied only between 17.9 and $21.7 \%$. This was significant $(P<0.05)$, with the control providing the wettest and 5 days' submergence at 40 DAA the driest seeds.

Variation in thousand seed dry weight of non-sprouted seeds at harvest maturity was limited (Table 1) but significant $(P<0.001)$. All submerged plants provided seeds lighter than the control; 9 DAA were the lightest, and 5 days' submergence provided consistently lighter seeds than 3 days' submergence.

The germination of freshly-harvested-non-sprouted seed (data not shown) did not $\operatorname{differ}(P>0.05)$ from that of dried-non-sprouted seeds. There was a tendency, however, for the fresh seeds to germinate more slowly than those dried before the test. This difference appeared to be accentuated with longer or later submergence.

Non-sprouted seeds achieved 89 to $97 \%$ normal germination in tests after desiccation to $15.1( \pm 0.2) \%$ moisture content and rehydration (Fig. 2). The two lowest values were following 5 days' submergence at 9 or 40 DAA, but differences amongst treatments were not significant $(P>0.05)$.

Dried, pre-harvest sprouted seeds showed reduced ability to germinate (Fig. 2). The reduction was greater the longer and later submergence occurred $(P<0.001)$. About half of the pre-harvest sprouted seeds were able to germinate normally with 3 days' submergence at 30-40 DAA following desiccation and rehydration (49-66\%, Fig. 2a), but few (<5\%, Fig. 2b) of those submerged for 5 days. Close examination indicated that the least pre-harvest sprouted seeds (only the micropyle open at harvest) were more likely to germinate normally subsequently than those with radicle already emerged. Seeds with root and shoot already emerged were rarely able to germinate normally. 
Seeds lost viability during hermetic storage at $40{ }^{\circ} \mathrm{C}$ with $14.9-15.3 \%$ moisture content with high ability to germinate initially declining in a negative sigmoid to zero (or almost) after 32 days (Fig. 3). The differences in these sigmoidal patterns of seed survival amongst blocks within a treatment or amongst treatments generally appeared small. The 27 different fitted curves are shown in Figure 3, however, as they could not be constrained to a common curve, common slope, or common origin $(P<0.001)$. The survival curves for 5 days' submergence at 9 DAA provided the lowest estimates of $K_{i}$ (Table 2), and so the lowest initial viability and the least "shoulder" before loss in viability was detected (Fig. 3f), whilst $K_{i}$ was greatest in the control. The observations for ability to germinate were close to zero in all 27 seed lots for the longest-durations of storage. They were below the fitted values provided by the negative cumulative normal distributions in each case.

Paired F-Tests were used to clarify any differences in $p_{50}$ resulting from the main treatment factors. Duration of submergence had no detectable effect on $p_{50}(P>0.25)$, whereas developmental stage did $(P<0.05)$, with $p_{50}$ shortest following submergence at 9 or 40 DAA and greatest in the control or submergence at 30 or 35 DAA.

Flowering date differed amongst the three genotypes in 2013, with 50\% anthesis earlier in Gleva (73 DAS) than IR64 (87 DAS) and IR64-Sub1 the latest (93 DAS). Accordingly, dates (but not durations from anthesis) of submergence and also harvest maturity varied amongst genotypes. When compared from anthesis onwards, the temporal changes in seed weight and moisture content were broadly similar amongst genotypes (Fig. 4). Final mean seed dry weight in Gleva $(29.5 \mathrm{mg}$, s.e. 0.34$)$ was much greater than the similar values recorded for IR64 (19.6 mg, s.e. 0.26) and IR64-Sub1 (20.3 mg, s.e. 0.31). Seed moisture contents at harvest maturity were similar amongst all three at 26.7 (Gleva), 28.2 (IR64), and 27.6\% (IR64-Sub1). 
Ability to germinate increased with developmental duration and was promoted by extending test durations and removing seed covering structures, particularly early in development (Fig. 5). Its development was delayed in IR64 relative to Gleva. Moreover, ability to germinate was promoted more in IR64 than in Gleva by longer test durations and seed covering structure removal. These differences persisted with only a third of seeds of IR64 but almost all of those of Gleva able to germinate within 21 days when freshlyharvested, intact seed were tested from the final harvest at harvest maturity (47 DAA, Fig. 5).

Pre-harvest sprouting was detected $(P<0.001)$ at harvest maturity as a result of plant submergence in 2013. The majority of treatments resulted in no sprouting. The exceptions were principally in seed from plants of Gleva submerged at 30 or 40 DAA with 8 (s.e. 2.5) or 67 (s.e. 2.5) \% of seeds sprouted, respectively; fewer than 1\% of seed from IR64 and IR64Sub1 plants submerged at 40 DAA sprouted (and none from earlier treatments). Two-way analysis of variance confirmed an interaction between submergence at different developmental stages and cultivar $(P<0.001)$ on pre-harvest sprouting.

Submergence of plants of Gleva or IR64-Sub1 reduced $(P<0.05)$ thousand seed dry weight of non-sprouted seeds, but not in IR64 $(P>0.05)$ (Fig. 6). Hence thousand seed dry weight was subject to interaction between genotype and submergence treatment $(P<0.001)$. Within Gleva, the differences amongst submergence at 10, 30 or 40 DAA were not significant but all these seeds were lighter than the control $(P<0.05)$. No differences were detected within IR64, but the small decline in thousand seed dry weight with submergence in IR64-Sub1 was significant $(P<0.05)$.

Ability to germinate normally in all seed lots (non-sprouted seeds) declined in a sigmoidal pattern during hermetic storage, such that all or almost all seeds of Gleva, IR64 and IR64-Sub1 had lost viability after 30, 44, and 41 days in storage, respectively. Seed 
survival curves, fitted by probit analysis to each seed lot separately, differed considerably amongst treatments (Table 3). The principal difference was amongst genotypes, with Gleva providing the smallest estimates of both $\sigma$ and $p_{50}$ (Table 3, Fig. 7). Estimates of $\sigma$ were similar between IR64 and IR64-Sub1, but those for $K_{i}$ and $p_{50}$ were greater for IR64-Sub1 than for IR64.

These differences were confirmed by the analyses. There were no differences in $K_{\mathrm{i}}, \sigma$, or $p_{50}$ within each genotype $(P>0.05)$, that is submergence was not damaging to the longevity of non-sprouted seeds, but estimates of $\sigma$ differed amongst genotypes $(P<0.05)$,

with Gleva shorter lived than IR64 and IR64-Sub1 (Table 3), as did $p_{50}(P<0.001)$ with Gleva (15-19 days) less than IR64 (24-29 days), which was less than IR64-Sub1 (31-35 days) (Fig. 7). Note, however, that there was no difference $(P>0.05)$ between the controls (no submergence) for IR64 and IR64-Sub1 .

\section{Discussion}

Simulated flooding of rice plants damaged seed, with substantial pre-harvest sprouting the longer the duration of submergence and the closer to harvest maturity it occurred (Fig. 1). The japonica rice Gleva was more sensitive to such damage than the indica rices, confirming that japonica cultivars are the more vulnerable to flooding damage (Fukao et al., 2006, 2009; Xu et al., 2006; Hattori et al., 2009; Bailey-Serres et al., 2010; Mickelbart et al., 2015).

Seed dormancy delays or prevents germination (Bewley et al., 2013) and is regulated by the genetics of the mother plant, developing embryo, and by environment (Bewley and Black, 1994; Taiz and Zeiger, 2006; Sugimoto et al., 2010). The mechanisms include restraint by seed covering tissues which delays imbibition and physically obstructs embryo growth, and embryo growth restriction by endogenous abscisic acid (Hilhorst, 1995; 
Sugimoto et al., 2010; Bewley et al., 2013). Developing seeds of Gleva declined in dormancy sooner than IR64 with seed covering structures playing a role in delaying germination, but this diminished as harvest maturity approached in Gleva (Fig. 5). This was to be expected: the longer the delay to harvest, the lower the dormancy (Pili, 1968); and japonica cultivars tend to be less dormant than indica cultivars and so more susceptible to pre-harvest sprouting (Sugimoto et al., 2010).

Pre-harvest sprouting damages seeds because the further germination progresses the less likely the seed or seedling is to survive considerable desiccation and later rehydration (Hong and Ellis, 1992). This was the case here (Fig. 2), but what are the consequences of plant submergence on seeds which did not sprout?

The reduced dry weight of non-sprouted seeds showed damage to seed physical quality following submergence at $9<30<35=40$ DAA $<$ control, and similarly submergence for $5 \mathrm{~d}<3 \mathrm{~d}$ (Table 1 ). While reduced photosynthate supply under water (Das et al., 2009; Singh et al., 2009) cannot be ruled out as a factor in the lighter non-sprouted seeds at 9 DAA, it does not explain the effect of submergence after seed filling ended. Cellular respiration after imbibition (Woodstock and Grabe, 1967; Footitt and Cohn, 1995; Tung and Serrano, 2011) may have caused dry matter loss for submergence from 30 DAA onwards. The strong interaction for thousand seed dry weight between genotypes and seed developmental stage at submergence in 2013, where cv. Gleva showed the greatest sensitivity to damage, combined with the lower dormancy of Gleva suggest activation of germination sensu strictu (Bewley et al., 2013) was the major cause of reduced seed dry weight.

The potential air-dry survival of seed that had sprouted was reduced at harvest maturity (Fig. 2). Hence, seed storage survival curves were determined only for non-sprouted seeds to avoid confusing air-dry survival results for the two cohorts. The effect of plant 
submergence on subsequent seed longevity was nil (Fig. 7c) or small (Figs 3, 7a, b) in the context of differences in longevity amongst different seed lots stored in the similar environments (e.g. Ellis and Roberts, 1981), or between japonica rice seed produced at different temperatures (Ellis et al., 1993), or between blocks within treatments here (Figs 3, 7).

In Gleva, for example, longevity was only reduced substantially after 5 days’ submergence at 9 or 40 DAA in 2012 and only increased substantially after 4 days' submergence at 30 DAA in 2013 (Fig. 3, Tables 2, 3). Close examination of the survival curves for Gleva submerged for 5 days at 9 DAA in 2012 (Fig. 3f) indicates a reduction in initial viability and more rapid loss in viability (Table 2). This treatment hadn't resulted in any pre-harvest sprouting (Fig. 2). It is possible that germination sensu strictu might have occurred however (for example, given the lighter thousand seed weight, Table 1) and subsequent air-dry survival therefore reduced in some seeds. However, longevity was not reduced in the closest parallel treatment (4 days' submergence at 10 DAA) in 2013 (Fig. 7a). On the other hand, the small improvement to seed longevity after submergence such as 4 days' at 30 DAA in the same genotype (Fig. 7a) might be ascribed to priming. Priming can benefit aged or immature seed (Burgass and Powell, 1984; Demir and Ellis, 1992; Powell et al., 2000; Butler et al., 2009a, b). However, we suggest that neither damage nor benefit occurred in non-sprouted seeds to any great extent in the current study: rather, subsequent airdry seed survival was remarkably resilient to submergence for 3-5 days in water for seeds resistant to pre-harvest sprouting.

The improved seed viability equation (Ellis and Roberts, 1980) estimates the value of $\sigma$ for seed lots in a known constant, hermetic, air-dry storage environment. Ellis and Hong (2007) provided two sets of estimates for the constants for rice: analysis of rice data alone; or 
including data from other species to provide a common temperature response. Seed storage moisture contents ranged from $14.5-14.9 \%$ in 2013 (Table 3). Assuming storage temperature ranged from $39-41{ }^{\circ} \mathrm{C}$, then the improved seed viability equation and viability constants for rice provides estimates of $\sigma$ for storage at $41{ }^{\circ} \mathrm{C}, 14.9 \%$ down to $39{ }^{\circ} \mathrm{C}, 14.5 \%$ of 11.1 to 17.2 days (rice data model) or 10.7 to 16.5 days (common temperature model). These ranges overlap with observations from the current research (Table 3) for the indica rices IR64 ( $\sigma=$ 12.0 - 19.0 days) and IR64-Sub1 ( $\sigma=11.6$ - 15.9 days). Hence the independent estimates (Ellis and Hong, 2007) provide good agreement with the current study for the indica rices.

In contrast, the observations for the japonica rice Gleva in $2013(\sigma=7.2-10.2$ days, Table 3) were below the independent estimates above. This difference was less in 2012 , where seed storage moisture contents ranged from 14.9 - $15.3 \%$ (Table 2): estimates of $\sigma$ at $39{ }^{\circ} \mathrm{C}, 14.9 \%$ to $41{ }^{\circ} \mathrm{C}, 15.3 \%$ are 9.9 - 15.3 days (rice data model) or $9.6-14.7$ days (common temperature model), with observations of 6.6 - 15.7 days in 2012 (Table 2), and so more variable than in 2013. Chang (1991) reported that japonica cultivars possess intrinsically poorer seed storage characteristics, whilst Ellis et al. (1993) reported estimates of $\sigma$ were ranked indica > javanica > japonica rice. The seed viability constants for rice (Ellis and Hong, 2007) therefore overestimated longevity in japonica cultivars, but provided good predictions in indica cultivars.

Differences between seeds produced by the indica rice IR64-Sub1 and its parent IR64 were negligible. Both were highly resistant to submergence in the reproductive phase, with almost no sprouted seeds detected, even in the extreme treatment of 4 days' submergence at 40 DAA $(<1 \%)$. Neither was subsequent seed longevity affected by submergence (Fig. 7). Hence, introgression of the Subl gene into cv. IR64 has not reduced resilience of the seed to submergence late in seed development and maturation; and the much greater dormancy of 
seed of IR64 and IR64-Sub1, compared with Gleva, provides this resilience. The Sub1 introgression was reported to provide yield advantage in completely-flooded conditions imposed to seedlings only 14 days old (Septiningsih et al., 2009; Singh et al., 2009; Sarkar and Bhattacharjee, 2011) and this was more evident with flooding for 7-14 days than shorter durations (Dar et al., 2013). Hence, whilst no benefit to seed was detected from the Subl introgression after flooding late in ontogeny here, a longer duration of flooding might have exposed differences.

IR64-Sub1 may have provided slightly greater longevity than IR64 under the same production and same storage environment but there was no difference amongst the controls (Fig. 7). Mapping of QTLs has revealed associations between ability to germinate under anoxia, maintenance of normal seedling growth, seed dormancy. and longevity caused by the co-location of QTLs in rice (Miura et al., 2002; Sasaki et al., 2005; Angaji et al., 2010; Septiningsih et al., 2013). Hence, further investigation of the longevity of seed of IR64 and IR64-Sub1 produced under the same conditions is warranted.

In conclusion, sprouting was the greatest consequence of plant submergence. Where dormancy prevented sprouting, there was only a small reduction in seed dry weight, and little or no impact on subsequent seed longevity. Thus dormancy in rice seed provides resilience to damage from flooding in planta for post-harvest air-dry survival as well as pre-harvest sprouting.

\section{Acknowledgements}


We thank the Royal Thai Government Scholarship, Thailand, for a scholarship to Sujittra

Tejakhod, Dr Tran D. Hong and Dr M. Martínez-Eixarch for advice, and Laurence Hansen, Caroline Hadley, and Liam Doherty for technical support.

\section{References}

Angaji SA, Septiningsih EM, Mackill DJ and Ismail AM. (2010) QTLs associated with tolerance of flooding during germination in rice (Oryza sativa L.). Euphytica 172, 159-168.

Bailey-Serres J, Fukao T, Ronald P, Ismail A, Heuer S and Mackill D. (2010)

Submergence tolerant rice: Subl's journey from landrace to modern cultivar. Rice 3, 138147.

Bewley JD and Black M. (1994) Seeds: physiology of development and germination, 2nd Edition. New York, Plenum Press.

Bewley JD, Bradford KJ, Hilhorst HWM and Nonogaki H. (2013) Seeds: physiology of development, germination and dormancy, 3rd Edition. New York: Springer.

Burgass RW and Powell AA. (1984) Evidence for repair processes in the invigoration of seeds by hydration. Annals of Botany 53, 753-757.

Butler LH, Hay FR, Ellis RH and Smith RD. (2009a) Post-abscission, pre-dispersal seeds of Digitalis purpurea remain in a developmental state that is not terminated by desiccation ex planta. Annals of Botany 103, 785-794.

Butler LH, Hay FR, Ellis RH, Smith RD and Murray TB. (2009b) Priming and re-drying improve the survival of mature seeds of Digitalis purpurea during storage. Annals of Botany 103, 1261-1270. 
Chang TT. (1991) Findings from a 28-year seed viability experiment. International Rice Research Newsletter 16, 5-6.

Dar MH, Janvry de A, Emerick K, Raitzer D and Sadoulet E. (2013) Flood-tolerant rice reduces yield variability and raises expected yield, differentially benefitting socially disadvantaged groups. Scientific Reports 3, 1-8.

Das KK, Panda D, Sarkar RK, Reddy JN and Ismail AM. (2009) Submergence tolerance in relation to variable floodwater conditions in rice. Environmental and Experimental Botany 66, 425-434.

Demir I and Ellis RH. (1992) Development of pepper (Capsicum annuum L.) seed quality. Annals of Applied Biology 121, 385-399.

Derera NF. (1989) The effect of preharvest rain: effect on grower, pp. 2-5 in Derera, N.F. (Ed.) Preharvest field sprouting in cereals. Boca Raton, Florida, CRC Press.

Devender-Reddy M and Mittra BN. (1985) Effect of complete plant submergence at different growth stages on grain yield, yield components and nutrient content of rice. Plant and Soil 86, 379-386.

Ellis RH. (2011) Rice seed quality development and temperature during late development and maturation. Seed Science Research 21, 95-101.

Ellis RH, Hong TD and Roberts EH. (1983) Safe procedures for the removal of rice seed dormancy. Seed Science and Technology 11, 77-112.

Ellis RH, Hong TD and Jackson MT. (1993) Seed production environment, time of harvest, and the potential longevity of seeds of three cultivars of rice (Oryza sativa L.). Annals of Botany 72, 583-590. 
Ellis RH and Hong TD. (1994) Desiccation tolerance and potential longevity of developing seeds of rice (Oryza sativa L.). Annals of Botany 73, 501-506.

Ellis RH and Hong TD. (2007) Seed longevity - moisture content relationships in hermetic and open storage. Seed Science and Technology 35, 423-431.

Ellis RH and Roberts EH. (1980) Improved equations for the prediction of seed longevity. Annals of Botany 45, 13-30.

Ellis RH and Roberts EH. (1981) The quantification of ageing and survival in orthodox seeds. Seed Science and Technology 9, 373-409.

Ellis RH and Yadav G. (2016) Effect of simulated rainfall during wheat seed development and maturation on subsequent seed longevity is reversible. Seed Science Research 26, 67-76.I FAO/IPGRI (1994) Genebank standards. Rome, Food and Agriculture Organisation of the United Nations/International Plant Genetic Resources Institute.

Footitt S and Cohn MA. (1995) Seed dormancy in red rice (Oryza sativa). IX. Embryo fructose-2,6-bisphosphate during dormancy breaking and subsequent germination. Plant Physiology 107, 1365-1370.

Fukao T, Xu K, Ronald PC and Bailey-Serres J. (2006) A variable cluster of ethylene response factor-like genes regulates metabolic and developmental acclimation responses to submergence in rice. The Plant Cell 18, 2021-2034.

Fukao T, Harris T and Bailey-Serres J. (2009) Evolutionary analysis of the Subl gene cluster that confers submergence tolerance to domesticated rice. Annals of Botany 103, 143150.

Gelin JR, Elias EM and Kianian SF. (2006) Evaluation of two durum wheat (Triticum turgidum L.) crossed for pre-harvest sprouting resistance. Field Crop Research 97, 188-196. 


\section{Hattori Y, Nagai K, Furukawa S, Song XJ, Kawano R, Sakakibara H, Wu J,}

Matsumoto T, Yoshimura A, Kitano H, Matsuoka M, Mori H and Ashikari M. (2009)

The ethylene response factors Snorkell and Snorkel2 allow rice to adapt to deep water.

Nature 460, 1026-1030.

Heydecker W and Gibbins BM. (1978) The 'priming' of seeds. Acta Horticulturae 83, 21323.

Heydecker W, Higgins J and Gulliver RL. (1973) Accelerated germination by osmotic seed treatment. Nature 246, 42-44.

Hilhorst HWM. (1995) A critical update on seed dormancy. I. Primary dormancy. Seed Science Research 5, 61-73.

Hong TD and Ellis RH. (1992) The survival of germinating orthodox seeds after desiccation and hermetic storage. Journal of Experimental Botany 43, 239-247.

IPCC (2013) Summary for policymakers, pp. 1-27 in Stocker TF; Qin D; Plattner G-K; Tignor M; Allen SK; Boschung J; Nauels A; Xia Y; Bex V; Midgley PM (Eds) Climate change 2013: the physical science basis. Contribution of working group I to the fifth assessment report of the Intergovernmental Panel on Climate Change. Cambridge, United Kingdom and New York, USA, Cambridge University Press.

ISTA (2013) International rules for seed testing. Bassersdorf, Switzerland, International Seed Testing Association.

Kotera A, Nawata E, Thao LV, Vuong NV and Sakuratani T. (2005) Effect of submergence on rice yield in the red river delta, Vietnam. Japanese Journal of Tropical Agriculture 49, 197-206.

Kotera A and Nawata E. (2007) Role of plant height in the submergence tolerance of rice: a simulation analysis using an empirical model. Agricultural Water Management 89, 49-58. 
Mackill DJ, Ismail AM, Pamplona AM, Sanchez DL, Carandang JJ and Septiningsih E. (2010) Stress tolerant rice varieties for adaptation to a changing climate. Crop, Environment and Bioinformatics 7, 250-259.

Mahbub AA, Rahman MS, Khanam M and Gomosta AR. (2005) Development of preharvest sprouting tolerance screening technique in rice. International Rice Research Notes 30, 50-51.

Martínez-Eixarch M and Ellis RH. (2015) Temporal sensitivity of rice seed development from spikelet fertility to viable mature seed to extreme-temperature. Crop Science 55, 354364.

Mickelbart MV, Hasegawa PM and Bailey-Serres J. (2015) Genetic mechanisms of abiotic stress tolerance that translate to crop yield stability. Nature Reviews Genetics 16, $237-$ 251.

Miura K, Lin SY, Yano M and Nagamine T. (2002) Mapping quantitative trait loci controlling seed longevity in rice (Oryza sativa L.). Theoretical and Applied Genetics 104, 981-986.

Pili EC. (1968) Dormancy of rice seeds - its causes and methods of breaking. Philippine Journal of Plant Industry 33, 127-133.

Powell AA, Yule LJ, Jing HC, Groot SPC, Bino RJ and Pritchard HW. (2000) The influence of aerated hydration seed treatment on seed longevity as assessed by the viability equations. Journal of Experimental Botany 51, 2031-2043.

Rao NK and Jackson MT. (1996) Seed production environment and storage longevity of japonica rices (Oryza sativa L). Seed Science Research 6, 17-21. 
Ram PC, Singh AK, Singh BB, Singh VK, Singh HP, Setter TL, Singh VP and Singh

RK. (1999) Environmental characterization of floodwater in eastern India: relevance to submergence tolerance of lowland rice. Experimental Agriculture 35, 141-152.

Reddy BB, Ghosh BC and Panda MM. (1985) Flood tolerance of rice at different crop growth stages as affected by fertilizer application. Plant and Soil 83, 255-263.

Roberts EH. (1963) An investigation of inter-varietal differences in dormancy and viability of rice seed. Annals of Botany 27, 365-369.

Sarkar RK and Bhattacharjee B. (2011) Rice genotypes with Subl QTL differ in submergence tolerance, elongation ability during submergence and re-generation growth at re-emergence. Rice 5, 1-11.

Sasaki K, Fukuta Y and Sato T. (2005) Mapping of quantitative trait loci controlling seed longevity of rice (Oryza sativa L.) after various periods of seed storage. Plant Breeding 124, 361-366.

Septiningsih EM, Ignacio J, Sendon PD, Sanchez D, Ismail A and Mackill D. (2013) QTL mapping and confirmation for tolerance of anaerobic conditions during germination derived from the rice landrace Ma-Zhan Red. Theoretical and Applied Genetics 126, 1357 1366.

\section{Septiningsih EM, Pamplona AM, Sanchez DL, Neeraja CN, Vergara GV, Heuer S,}

Ismail A.M and Mackill DJ. (2009) Development of submergence-tolerant rice cultivars: the Subl locus and beyond. Annals of Botany 103, 151-160.

Sharma AR and Ghosh A. (1999) Submergence tolerance and yield performance of lowland rice as affected by agronomic management practices in eastern India. Field Crops Research 63, 187-189. 
Singh N, Dang TTM, Vergara GV, Pandey DM, Sanchez D, Neeraja CN, Septiningsih EM, Mendioro M, Tecson-Mendoza EM, Ismail AM, Mackill DJ and Heuer S. (2010) Molecular marker survey and expression analyses of the rice submergence-tolerance genes SUB1A and SUB1C. Theoretical and Applied Genetics 121, 1441-1453.

Singh S, Mackill DJ and Ismail AM. (2009) Response of Subl rice introgression lines to submergence in the field: yield and grain quality. Field Crops Research 113, 12-23.

Singh S, Mackill DJ and Ismail AM. (2011) Tolerance of longer-term partial stagnant flooding is independent of the Subl locus in rice. Field Crops Research 121, 311-323.

Sugimoto K, Takeuchi Y, Ebana K, Miyao A, Hirochika H, Hara N, Ishiyama K, Kobayashi M, Ban Y, Hattori T and Yano M. (2010) Molecular cloning of Sdr4, a regulator involved in seed dormancy and domestication of rice. Proceedings of the National Academy of Sciences of the USA 107, 5792-5797.

Summerfield RJ, Collinson ST, Ellis RH, Roberts EH and Penning de Vries FWT. (1992) Photothermal responses of flowering in rice (Oryza sativa L.). Annals of Botany 69, 101-112.

Taiz L and Zeiger E. (2006) Plant physiology, 4th Edition. Massachusetts, Sinauer Associates.

Tung LD and Serrano EP. (2011) Effect of warm water in breaking dormancy of rice seed. Omonrice 18, 129-136.

Wassmann R, Jagadish SVK, Heuer S, Ismail A, Redona E, Serraj R, Singh RK, Howell G, Pathak H and Sumfleth K. (2009) Climate change affecting rice production: the physiological and agronomic basis for possible adaptation strategies, pp. 59-122 in L. S. Donald, L.S. (Ed.) Advances in agronomy. New York, Academic Press. 
Whitehouse KJ, Hay FR and Ellis RH. (2015) Increases in the longevity of desiccationphase developing rice seeds: response to high-temperature drying depends on harvest moisture content. Annals of Botany 116, 245-259.

Whitehouse KJ, Hay FR and Ellis RH. (2017) High-temperature stress during drying improves subsequent rice (Oryza sativa L.) seed longevity. Seed Science Research 27, 281291.

Woodstock LW and Grabe DF. (1967) Relationships between seed respiration during imbibition and subsequent seedling growth in Zea mays L. Plant Physiology 42, 1071-1076.

Xu K, Xu X, Fukao T, Canlas P, Maghirang-Rodriguez R, Heuer S, Ismail AM, BaileySerres J, Ronald PC and Mackill DJ. (2006) SublA is an ethylene-response-factor-like gene that confers submergence tolerance to rice. Nature 442, 705-708.

Yadav G and Ellis RH. (2016) Development of ability to germinate and of longevity in airdry storage in wheat seed crops subjected to rain shelter or simulated supplementary rainfall. Seed Science Research 26, 332-341.

Yoshida S. (1981) Fundamentals of rice crop science. Los Baños, Philippines, IRRI.

Yoshida S, Forno D, Cock JH and Gomez KA (1976) Laboratory manual for physiological studies of rice, 3rd Edition. Los Baños, Philippines, IRRI. 


\section{Figure Legends}

Figure 1. Pre-harvest sprouting (vertical bars represent \pm s.e.) in response to $3(\square)$ or 5 ( $\mathbf{a})$ days' submergence of plants of japonica rice cv. Gleva in water at different stages of development (Control $=$ no submergence). Pre-harvest sprouting was assessed in samples harvested 47 DAA (harvest maturity) and first dried to 11-12\% moisture content. Columns with a different letter indicate a significant difference $(P<0.05)$ using Tukey's Multiple Range Test.

Figure 2. Ability of dried seeds, harvested 47 DAA, of cv. Gleva to germinate

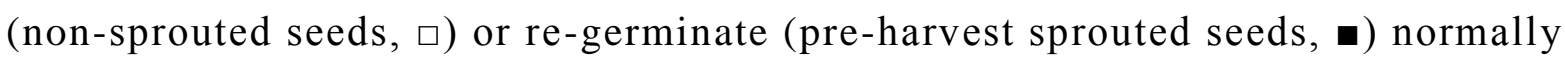
(vertical bars represent \pm s.e.) after previous submergence of plants in water for 3 (a) or 5 (b) days at 9, 30, 35, or 40 DAA (Control = no submergence; combined population of pre-harvest sprouted or not seeds, $\square$ ).

Figure 3. Seed storage survival (\% normal germination plotted against period in hermetic storage at $40{ }^{\circ} \mathrm{C}$ with $15.1 \pm 0.2 \%$ moisture content) of non-sprouted seeds of japonica rice cv. Gleva harvested at 47 DAA (harvest maturity) from plants not submerged (Control, a), or submerged in water for 3 days (b - e) at 9 (b), 30 (c), 35 (d), or 40 DAA (e), or for 5 days (f - i) at 9 (f), 30 (g), 35 (h), or 40 DAA. Observations are shown for seed lots from each block $(1, \varangle ; 2, \mathbf{\square} ; 3, \boldsymbol{\Delta})$ together with the fitted negative cumulative normal distributions $\left(1, \ldots ; 2,---{ }_{---} ; 3\right.$, - .). The latter are quantified in Table 2. 
Figure 4. Fresh $(\bullet)$ and dry $(\boldsymbol{\Delta})$ weight (mean \pm s.e.) and moisture content (Block $1 ; \bullet$, Block $2 ; 0$ ) of seeds from control (non-submerged) plants of japonica rice cv. Gleva (a), and the indica rices IR64 (b) and IR64-Sub1 (c) grown at $28 / 20{ }^{\circ} \mathrm{C}(11 \mathrm{~h} / 13 \mathrm{~h})$. The intersect of the solid lines represents the end of grain filling [mass maturity, i.e. 27.6 (s.e. 1.17 ), 27.5 (s.e. 1.21 ), or 24.0 (s.e. 3.10 ) DAA in a, b, c respectively]; $R^{2}$ values shown are for these broken-stick regression lines.

Figure 5. Ability to germinate normally of fresh (i.e. not dried) seed of cvs Gleva (•) and IR64 (•) harvested serially during seed development and maturation, from plants grown at $28 / 20{ }^{\circ} \mathrm{C}(11 \mathrm{~h} / 13 \mathrm{~h})$, after 21 days in test (.......) at $34 / 11^{\circ} \mathrm{C}(16 \mathrm{~h} / 8 \mathrm{~h})$, or when combined with subsequent removal of seed covering structures from ungerminated seeds and tested for an additional 7 days ( $~-~)$. Seed moisture content (\%) at harvest is shown for each observation.

Figure 6. The effect of submergence for four days in water at 10, 30, or 40 DAA $(\mathrm{C}=$ control, no submergence $)$ of rice plants rice cvs Gleva, IR64 and IR64-Sub1 on subsequent 1000 seed dry weight ( $0 \%$ moisture content; vertical bars represent \pm s.e.) for non-sprouted seed samples harvested 46 DAA (harvest maturity).

Figure 7. Effect of submergence of plants of rice cvs Gleva (a), IR64 (b), and IR64-Sub1 (c) in water for 4 days at 10, 30 or 40 DAA on the subsequent 
longevity ( $p_{50}$; vertical bars represent \pm s.e.) of seeds harvested at harvest maturity (46 DAA) and stored hermetically at $40^{\circ} \mathrm{C}$ with $14.7 \pm 0.2 \%$ moisture content for each block $(1, \bullet ; 2, \boldsymbol{\square})$ and the mean value $(\bullet)$. Further information on the fitted seed survival curves is provided in Table 3. 
Table 1. Thousand seed dry weight ( $0 \%$ moisture content) of non-sprouted rice cv. Gleva at harvest maturity (47 DAA) after submergence for 0 (control, repeated in both columns), 3, or 5 days at different seed developmental stages.

\begin{tabular}{ccc}
\hline Treatment & \multicolumn{2}{c}{ 1000 seed dry weight $($ g) (s.e.) } \\
\cline { 2 - 3 } (DAA) & 3 d submergence & 5 d submergence \\
\cline { 2 - 3 } Control & {$[29.5(0.22)]$} & {$[29.5(0.22)]$} \\
9 & $28.4(0.19)$ & $27.4(0.16)$ \\
30 & $28.6(0.19)$ & $27.9(0.19)$ \\
35 & $29.3(0.15)$ & $28.7(0.18)$ \\
40 & $29.1(0.35)$ & $28.5(0.21)$ \\
\hline
\end{tabular}


Table 2. Seed longevity (parameters of seed viability equation, fitted by probit analysis) of japonica rice cv. Gleva, harvested at 47 DAA (harvest maturity) in 2012 after submergence in water for 0 (control), 3 , or 5 days at 9-40 DAA, in hermetic storage at $40^{\circ} \mathrm{C}$ with moisture contents shown. The $95 \%$ confidence intervals (CI) are shown for $p_{50}$.

\begin{tabular}{|c|c|c|c|c|c|c|c|c|}
\hline $\mathrm{DD}^{1}$ & $\mathrm{DS}^{2}$ & $\mathbf{B}^{3}$ & MC $^{4}$ & $K_{i}$ (s.e.) & $1 / \sigma$ (s.e.) & $\sigma(d)$ & $p_{50}(\mathrm{~d}$, s.e. $)$ & $95 \% \mathrm{CI}$ \\
\hline \multirow[t]{3}{*}{$\mathrm{Nil}^{5}$} & Od & 1 & 15.1 & $1.92(0.103)$ & $0.081(0.006)$ & 12.3 & $23.7(0.95)$ & $22.1-25.8$ \\
\hline & & 2 & 15.2 & $2.68(0.136)$ & $0.152(0.007)$ & 6.6 & $17.6(0.36)$ & $16.9-18.3$ \\
\hline & & 3 & 14.9 & $2.37(0.125)$ & $0.104(0.007)$ & 9.6 & $22.8(0.65)$ & $21.6-24.1$ \\
\hline \multirow[t]{6}{*}{9} & $3 d$ & 1 & 15.2 & $1.79(0.074)$ & $0.093(0.004)$ & 10.7 & $19.2(0.57)$ & $18.2-20.4$ \\
\hline & & 2 & 15.0 & $2.17(0.113)$ & $0.106(0.006)$ & 9.4 & $20.5(0.56)$ & $19.5-21.6$ \\
\hline & & 3 & 15.0 & $2.07(0.107)$ & $0.125(0.006)$ & 8.0 & $16.6(0.43)$ & $15.7-17.4$ \\
\hline & $5 \mathrm{~d}$ & 1 & 15.2 & $1.35(0.070)$ & $0.063(0.006)$ & 15.7 & $21.3(1.58)$ & $18.8-24.9$ \\
\hline & & 2 & 15.0 & $1.40(0.083)$ & $0.094(0.005)$ & 10.6 & $14.9(0.47)$ & $14.0-15.8$ \\
\hline & & 3 & 15.0 & $1.52(0.088)$ & $0.103(0.006)$ & 9.7 & $14.8(0.47)$ & $13.9-15.7$ \\
\hline \multirow[t]{6}{*}{30} & $3 \mathrm{~d}$ & 1 & 15.1 & $2.19(0.094)$ & $0.108(0.006)$ & 9.3 & $20.3(0.59)$ & $19.2-21.5$ \\
\hline & & 2 & 15.1 & $2.24(0.113)$ & $0.115(0.006)$ & 8.7 & $19.4(0.48)$ & $18.5-20.4$ \\
\hline & & 3 & 15.0 & $2.22(0.109)$ & $0.113(0.005)$ & 8.9 & $19.7(0.44)$ & $18.8-20.6$ \\
\hline & $5 \mathrm{~d}$ & 1 & 15.3 & $1.86(0.080)$ & $0.083(0.005)$ & 12.0 & $22.4(0.80)$ & $21.0-24.1$ \\
\hline & & 2 & 15.3 & $2.47(0.123)$ & $0.137(0.007)$ & 7.3 & $18.0(0.42)$ & $17.2-18.8$ \\
\hline & & 3 & 14.9 & $2.49(0.121)$ & $0.118(0.006)$ & 8.5 & $21.1(0.45)$ & $20.3-22.0$ \\
\hline \multirow[t]{6}{*}{35} & $3 d$ & 1 & 15.1 & $2.04(0.090)$ & $0.098(0.006)$ & 10.2 & $20.8(0.71)$ & $19.5-22.3$ \\
\hline & & 2 & 15.3 & $2.33(0.119)$ & $0.112(0.006)$ & 8.9 & $20.8(0.50)$ & $19.9-21.8$ \\
\hline & & 3 & 15.0 & $2.35(0.114)$ & $0.111(0.005)$ & 9.0 & $21.1(0.47)$ & $20.2-22.0$ \\
\hline & $5 \mathrm{~d}$ & 1 & 15.1 & $2.23(0.098)$ & $0.095(0.005)$ & 10.6 & $23.6(0.80)$ & $22.1-25.2$ \\
\hline & & 2 & 15.2 & $2.51(0.126)$ & $0.120(0.006)$ & 8.3 & $20.8(0.48)$ & $19.9-21.8$ \\
\hline & & 3 & 15.0 & $2.14(0.105)$ & $0.115(0.005)$ & 8.7 & $18.6(0.44)$ & $17.7-19.4$ \\
\hline \multirow[t]{6}{*}{40} & $3 d$ & 1 & 15.0 & $1.54(0.070)$ & $0.081(0.005)$ & 12.4 & $19.1(0.72)$ & $17.8-20.6$ \\
\hline & & 2 & 15.2 & $2.24(0.112)$ & $0.117(0.006)$ & 8.5 & $19.2(0.47)$ & $18.3-20.1$ \\
\hline & & 3 & 14.9 & $2.06(0.105)$ & $0.107(0.006)$ & 9.3 & $19.2(0.49)$ & $18.3-20.2$ \\
\hline & $5 d$ & 1 & 14.9 & $1.73(0.076)$ & $0.100(0.005)$ & 10.0 & $17.4(0.56)$ & $16.4-18.6$ \\
\hline & & 2 & 15.1 & $2.16(0.113)$ & $0.123(0.007)$ & 8.1 & $17.5(0.48)$ & $16.6-18.5$ \\
\hline & & 3 & 15.1 & $1.48(0.098)$ & $0.092(0.006)$ & 10.8 & $16.0(0.58)$ & $14.9-17.2$ \\
\hline
\end{tabular}

${ }^{1} \mathrm{DD}=$ Duration of development until submergence (DAA)

${ }^{2} \mathrm{DS}=$ Duration of submergence (days)

${ }^{3} \mathrm{~B}=$ block

${ }^{4} \mathrm{MC}=$ moisture content of storage $(\%)$

${ }^{5}$ Control treatment (plants not submerged) 
Table 3. Seed longevity (parameters of seed viability equation, fitted by probit analysis) of rice cvs Gleva, IR64, and IR64-Sub1harvested at harvest maturity in 2013 after submergence in water for 0 (control) or 4 days at $10-40 \mathrm{DAA}$, in hermetic storage at $40^{\circ} \mathrm{C}$ with moisture contents shown. The $95 \%$ confidence intervals (CI) are shown for $p_{50}$.

\begin{tabular}{|c|c|c|c|c|c|c|c|c|}
\hline $\mathrm{Cv}^{1}$ & $\overline{D^{2}}$ & $\overline{\mathbf{B}^{3}}$ & $\mathbf{M C}^{4}$ & $K_{i}$ (s.e.) & $1 / \sigma$ (s.e.) & $\sigma(\mathbf{d})$ & $p_{50}(\mathrm{~d}$, s.e. $)$ & $95 \% \mathrm{CI}$ \\
\hline \multirow[t]{8}{*}{ Gleva } & $C^{5}$ & 1 & 14.7 & $2.20(0.074)$ & $0.138(0.004)$ & 7.2 & $15.9(0.22)$ & $15.5-16.4$ \\
\hline & & 2 & 14.8 & $2.01(0.070)$ & $0.137(0.004)$ & 7.3 & $14.6(0.22)$ & $14.2-15.1$ \\
\hline & 10 & 1 & 14.6 & $2.06(0.070)$ & $0.135(0.004)$ & 7.4 & $15.3(0.22)$ & $14.8-15.7$ \\
\hline & & 2 & 14.6 & $2.05(0.070)$ & $0.136(0.004)$ & 7.4 & $15.1(0.22)$ & $14.7-15.6$ \\
\hline & 30 & 1 & 14.8 & $2.29(0.070)$ & $0.108(0.003)$ & 9.3 & $21.2(0.28)$ & $20.7-21.8$ \\
\hline & & 2 & 14.7 & $2.08(0.068)$ & $0.122(0.004)$ & 8.2 & $17.1(0.24)$ & 16.6-17.6 \\
\hline & 40 & 1 & 14.5 & $1.66(0.089)$ & $0.098(0.007)$ & 10.2 & $16.4(0.47)$ & $15.6-17.4$ \\
\hline & & 2 & 14.5 & $1.94(0.100)$ & $0.119(0.008)$ & 8.4 & $16.8(0.48)$ & $16.0-17.8$ \\
\hline \multirow[t]{8}{*}{ IR64 } & $C^{5}$ & 1 & 14.5 & $1.63(0.052)$ & $0.058(0.002)$ & 17.3 & $28.2(0.48)$ & $27.3-29.2$ \\
\hline & & 2 & 14.7 & $1.96(0.059)$ & $0.066(0.002)$ & 15.1 & $29.7(0.44)$ & $28.9-30.6$ \\
\hline & 10 & 1 & 14.7 & $1.46(0.049)$ & $0.053(0.002)$ & 19.0 & $27.6(0.51)$ & $26.7-28.7$ \\
\hline & & 2 & 14.6 & $1.76(0.056)$ & $0.084(0.002)$ & 12.0 & $21.0(0.34)$ & 20.4-21.7 \\
\hline & 30 & 1 & 14.5 & $2.03(0.060)$ & $0.077(0.002)$ & 12.9 & $26.2(0.37)$ & $25.5-26.9$ \\
\hline & & 2 & 14.6 & $1.28(0.046)$ & $0.053(0.002)$ & 19.0 & $24.5(0.48)$ & $23.5-25.4$ \\
\hline & 40 & 1 & 14.5 & $1.51(0.050)$ & $0.060(0.002)$ & 16.8 & $25.4(0.45)$ & $24.6-26.3$ \\
\hline & & 2 & 14.6 & $1.91(0.058)$ & $0.073(0.002)$ & 13.7 & $26.1(0.38)$ & $25.3-26.8$ \\
\hline IR64 & $\mathrm{C}^{5}$ & 1 & 14.9 & $2.18(0.065)$ & $0.065(0.002)$ & 15.4 & $33.6(0.48)$ & $32.6-34.6$ \\
\hline \multirow[t]{7}{*}{ Sub 1} & & 2 & 14.7 & $2.93(0.092)$ & $0.087(0.003)$ & 11.6 & $34.0(0.48)$ & $33.2-34.8$ \\
\hline & 10 & 1 & 14.9 & $2.09(0.062)$ & $0.070(0.002)$ & 14.5 & $30.2(0.48)$ & 29.3-31.0 \\
\hline & & 2 & 14.8 & $2.50(0.075)$ & $0.078(0.003)$ & 12.9 & $32.2(0.48)$ & $31.4-33.0$ \\
\hline & 30 & 1 & 14.9 & $2.64(0.082)$ & $0.073(0.003)$ & 13.7 & $36.2(0.48)$ & $35.3-37.2$ \\
\hline & & 2 & 14.5 & $2.19(0.065)$ & $0.066(0.002)$ & 15.2 & $33.3(0.48)$ & $32.3-34.2$ \\
\hline & 40 & 1 & 14.8 & $2.17(0.065)$ & $0.064(0.002)$ & 15.7 & $34.2(0.48)$ & $33.2-35.2$ \\
\hline & & 2 & 14.7 & $2.03(0.061)$ & $0.063(0.002)$ & 15.9 & $32.4(0.48)$ & $31.5-33.4$ \\
\hline
\end{tabular}

\footnotetext{
${ }^{1} \mathrm{Cv}=$ Cultivar

${ }^{2} \mathrm{DD}=$ Duration of development until submergence (DAA)

${ }^{3} \mathrm{~B}=$ block

${ }^{4} \mathrm{MC}=$ moisture content of storage $(\%)$

${ }^{5}$ Control treatment (plants not submerged)
} 


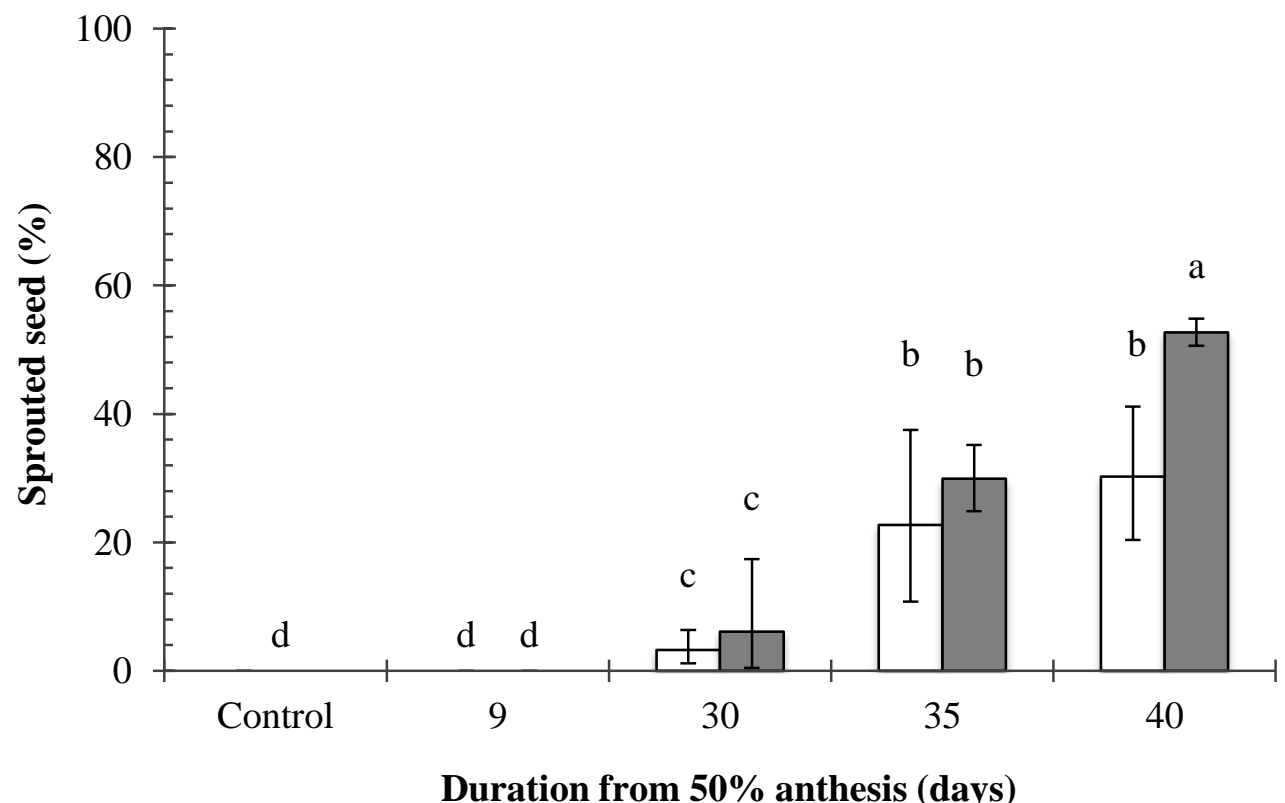

Figure 1. 


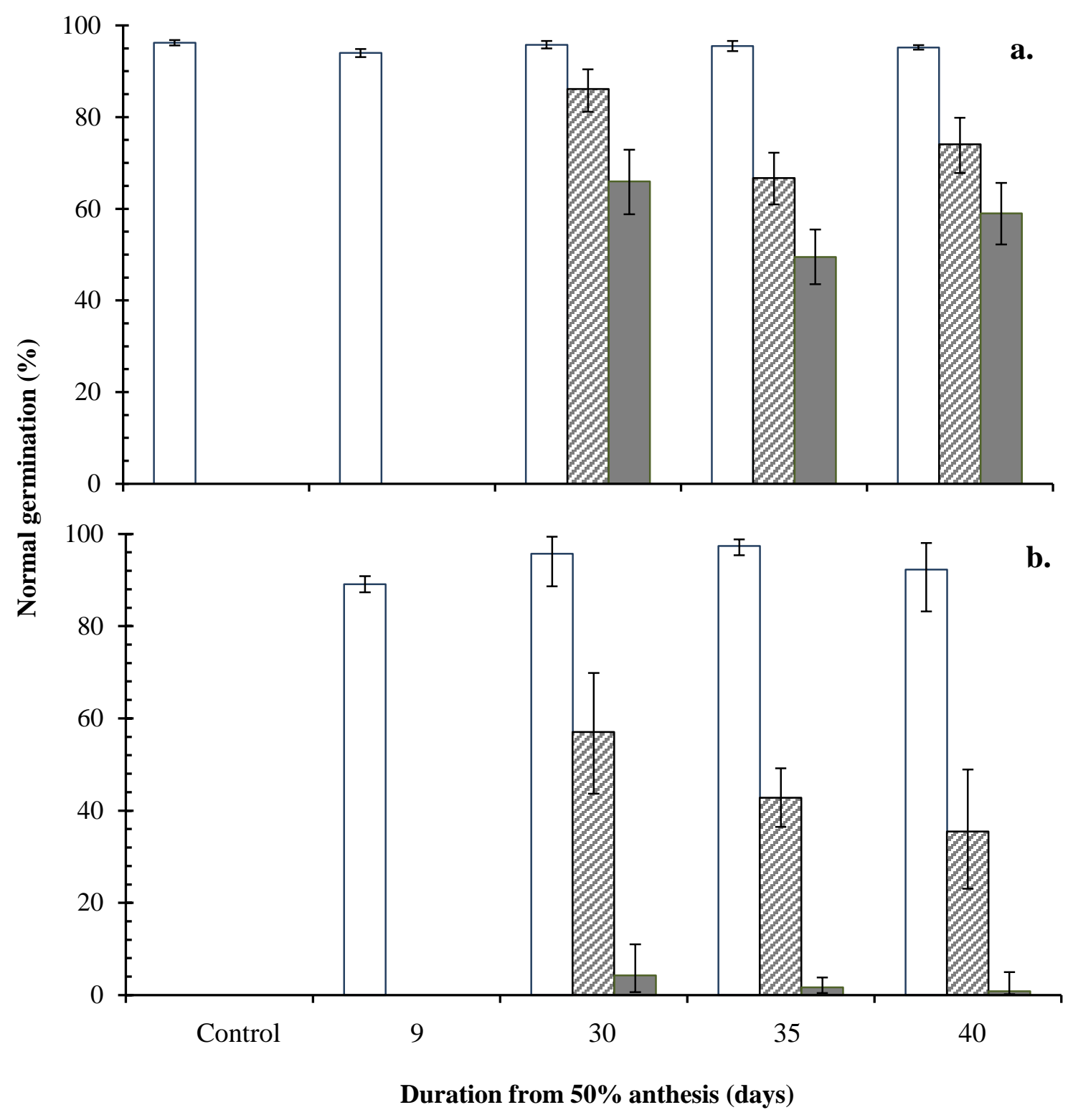

Figure 2 

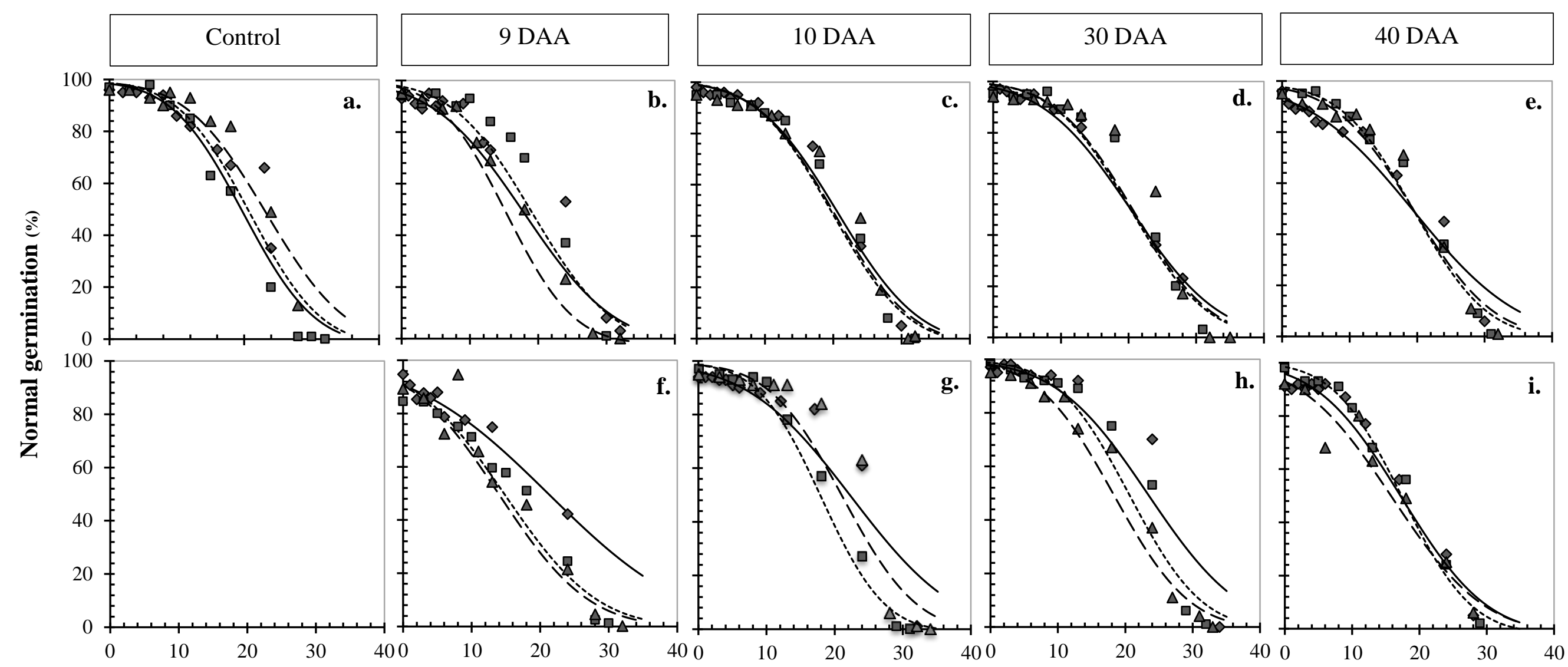

Storage period (days)

Figure 3 


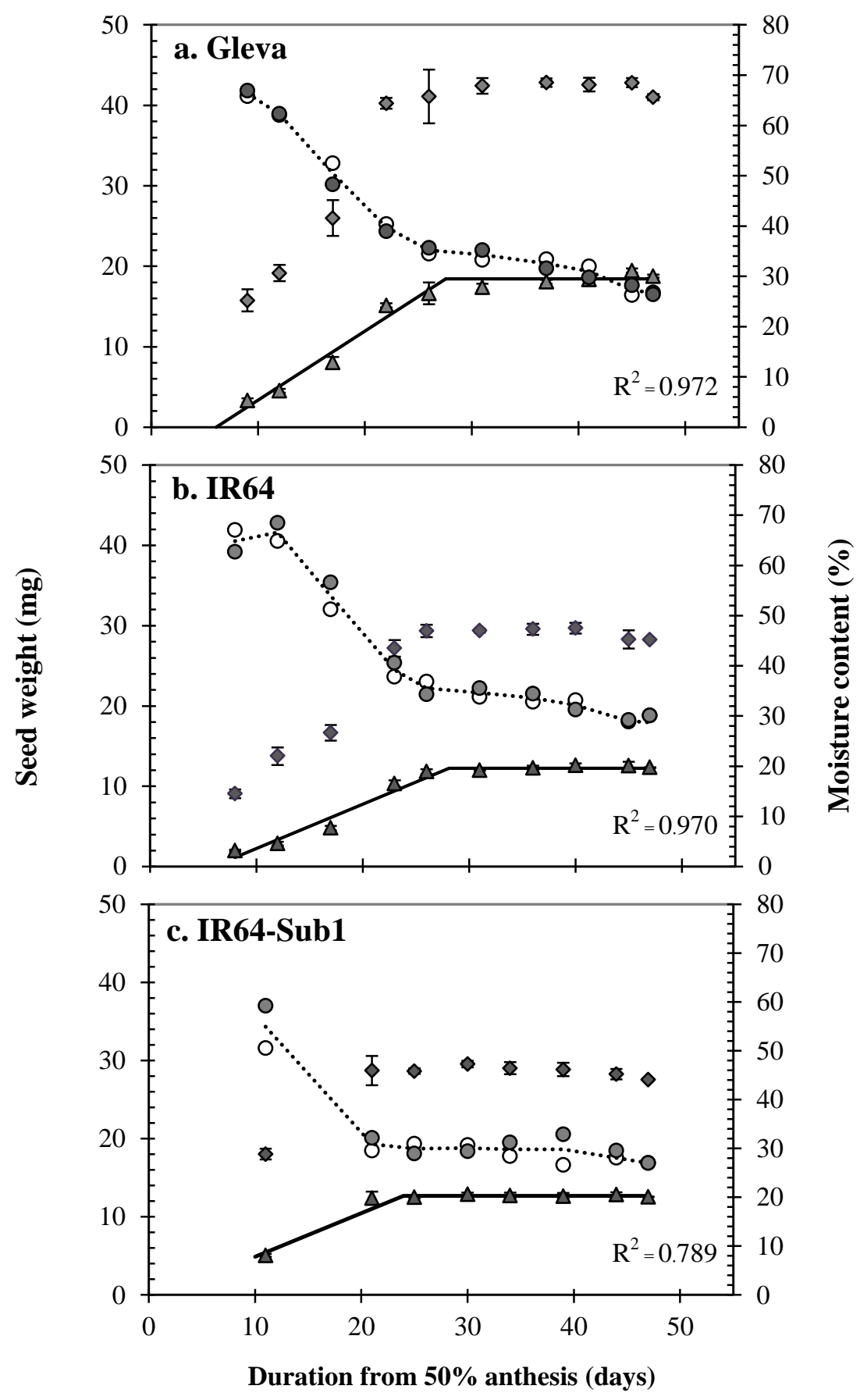

Figure 4 


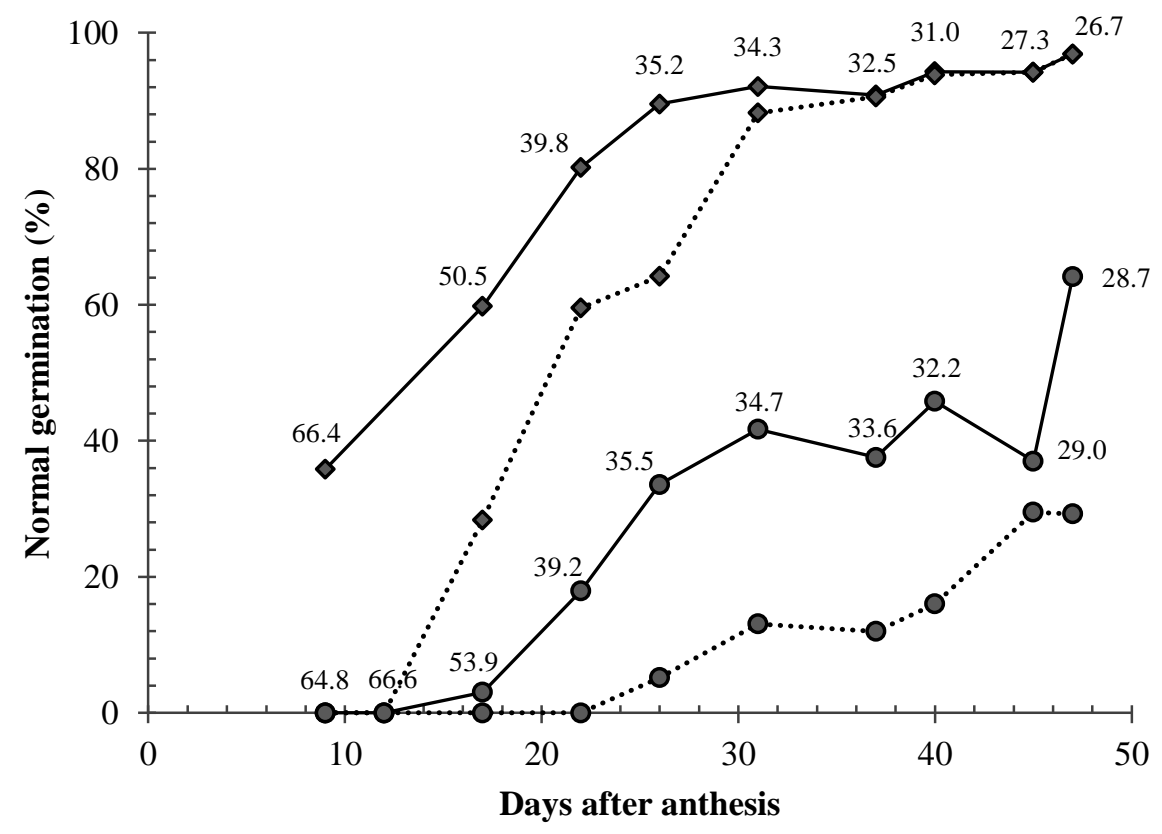

Figure 5 


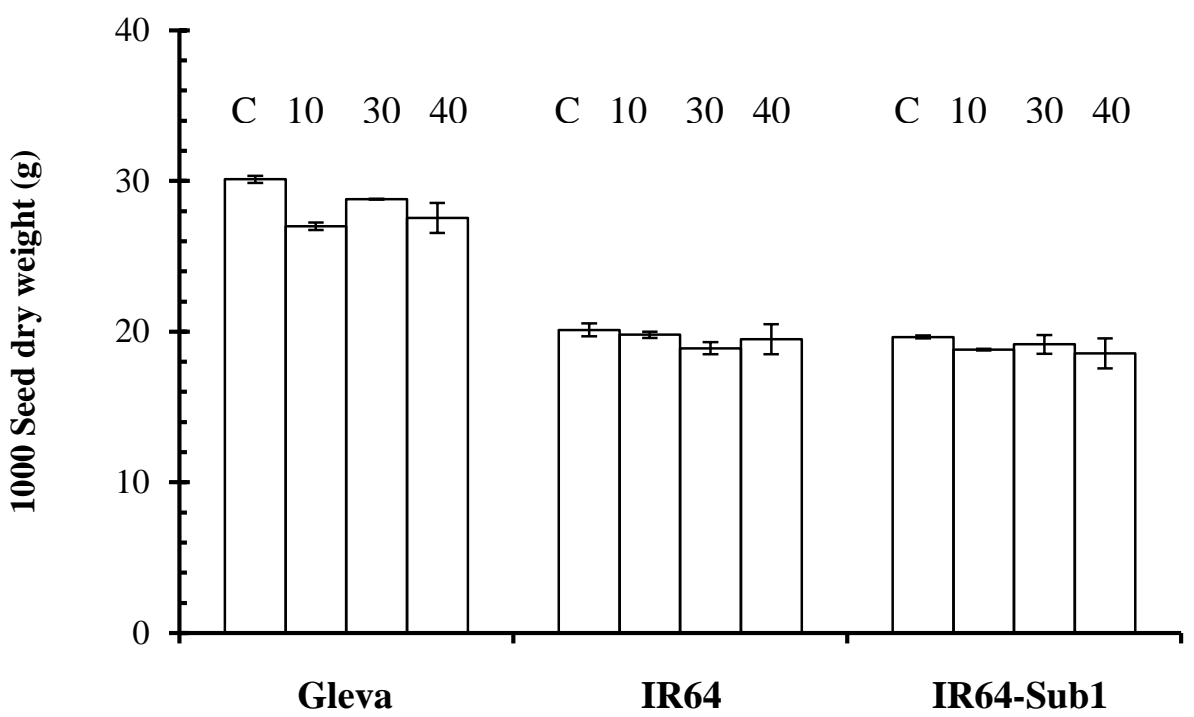

Figure 6 


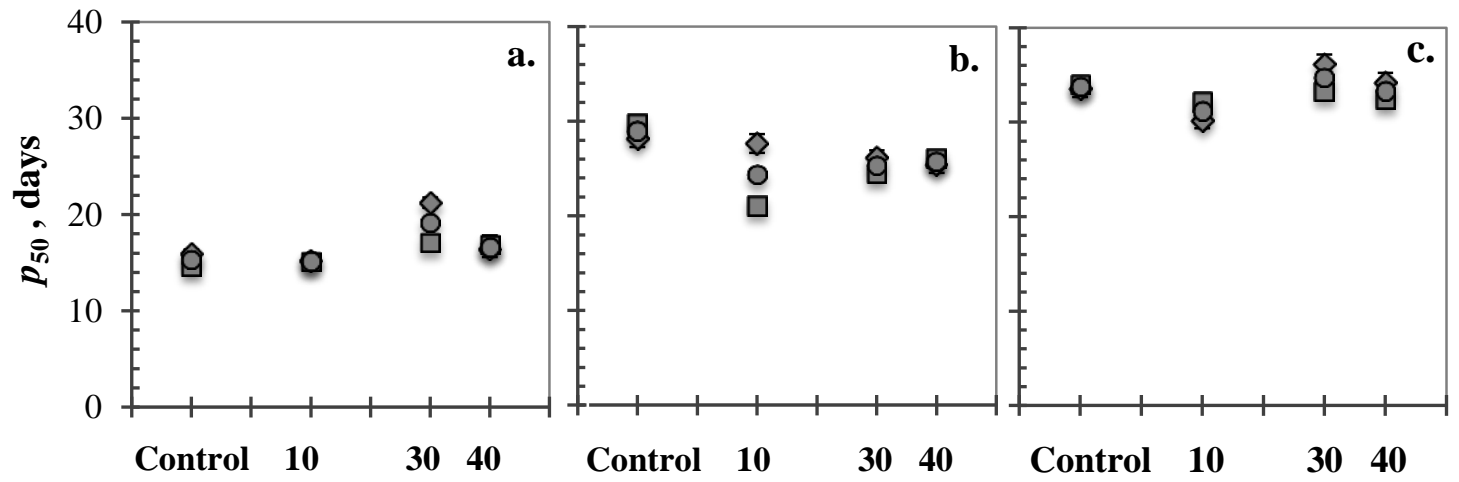

Duration from $50 \%$ anthesis (days)

Figure 7 